\title{
Kepuasan Pasien Terhadap Kualitas Pelayanan di Tempat Pendaftaran Pasien Rawat Jalan Puskesmas Kretek Bantul Yogyakarta
}

\author{
Wahyu Kuntoro ${ }^{1}$, Wahyudi Istiono ${ }^{2}$ \\ Program Diploma III Rekam Medis Fakultas Sekolah Vokasi Universitas Gajah Mada ${ }^{1}$ \\ Fakultas Kedokteran Universitas Gajah Mada² \\ gepptta@yahoo.co.id ${ }^{1}$, wistiono@gmail.com ${ }^{2}$
}

\begin{abstract}
ABSTRAK
Latar Belakang: Pelayanan yang memuaskan dan berkualitas akan membentuk loyalitas pasien/pelanggan, dan kepuasan sangat erat hubungannya dengan "word of mouth".Efek selanjutnya akan berlanjut pada proses terbentuknya citra puskesmas yang meningkat. Hal ini dikarenakan kondisi persaingan yang sangat ketat. Maka setiap puskesmas akan berusaha untuk menempatkan dirinya sebaik mungkin dimata pasien/pelanggannya agar dapat dipercaya untuk memenuhi kebutuhannya dalam bidang kesehatan. TPP di Puskesmas Kretek Bantul Yogyakarta masih terdapat komplain pasien terhadap kecepatan pelayanan petugas. Diperlukan pengukutan terhadap tingkap kepuasan berdasarkan guna mengetahui kualitas pelayanan.

Tujuan: Mengetahui distribusi kepuasan pasien berdasarkan lima dimensi kualitas jasa pelayanan, yaitu tangibles, reliability, responsiveness, assurance, emphaty; dan mengetahui perbedaan tingkat kepuasan pasien berdasarkan karakteristik.

Metode: Jenis penelitian yang digunakan adalah penelitian analitik kuantitatif dengan rancangan Cross sectional dan teknik sampel yang digunakan adalah purposive accidental. Sampel yang diambil sebanyak 100 orang pasien. Teknik pengumpulan data menggunakan kuesioner dan observasi. Teknik analisa data menggunakan statistik inferensial (uji Kruskal-Wallis dan Mann-Whitney).

Hasil: Berdasarkan hasil penelitian 84\% menyatakan puas terhadap pelayanan di TPP. Dimensi yang perlu ditingkatkan adalah dimensi Assurance pada bagian kemampuan petugas. Berdasarkan hasil uji statistik Kruskal-Wallis dan MannWhitney ada perbedaan tingkat kepuasan pasien terhadap pelayanan di tempat pendaftaran pasien rawat jalan berdasarkan karakteristik pendidikan pasien, dengan nilai $\mathrm{p}$ ( sig) sebesar 0.003 .

Kesimpulan: Distribusi kepuasan secara menyeluruh mayoritas pada kategori puas. Tidak ada perbedaan kepuasan berdasarkan karakteristik Jenis kelamin, Usia, dan Pekerjaan. Namun ada perbedaan kepuasan yang bermakna pada karakteristik pendidikan.

Kata kunci: lima dimensi kualitas jasa, karakteristik pasien, tempat pendaftaran pasien rawat jalan, tingkat kepuasan pasien.
\end{abstract}

\begin{abstract}
Background: Satisfactory and qualified service will shape patients/customers loyalty. Satisfaction is closely related to word of mouth; thus satisfactory service will result in new customers. Further effect will be continued on the process of improving Puskesmas (Health Centre) image forming. It is because the very strict competition. Thus, each Puskesmas will try to place themselves as good as possible in front of patients/customers so that they are trustworthy to fullfill their needs in health field. Outpatient registration at Puskesmas Kretek Bantul Yogyakarta still their patient complaint to speed service officer.

Objectives: Finding patients' satisfaction distribution based on five quality dimensions of service, such as tangibles, reliability, responsiveness, assurance, emphaty and difference of patients' satisfaction level based on characteristics.

Method: Research type which is utilized by analitic research with quantitative approach and Cross Sectional. The sample technique is purposive accidental. 100 people patients are taken as the samples. The data collection technique utilizes questionnaire and observation. The data analysis technique uses inferencial statistic using Kruskal-Wallis and MannWhitney statistical test.

Result: Based on the research result, $84 \%$ states satisfied. Dimension needs to be improved is the dimension of Assurance on the part of the officer's abilities. Based on the Kruskal-Wallis and Mann-Whitney statistical test result, there is patients' satisfaction level difference towards service at outpatient registration place based on educational characteristics, with a value of $p$ (sig) 0.003 .

Conclusions: The overall satisfaction distribution of the majority in the satisfied category. Judging from each dimension, there is still a category of dissatisfaction on the assurance dimension, especially the patient item is sure of the officer's ability. There is no difference in satisfaction based on the characteristics of Gender, Age, and Occupation. However, there are significant differences in satisfaction in education characteristics.
\end{abstract}

Keywords: patients' satisfaction, five service quality dimension, outpatient registration place, patients' characteristics. 


\section{PENDAHULUAN}

Kepuasan pasien didefinisikan sebagai respon pelanggan terhadap ketidaksesuaian antara tingkat kepentingan sebelumnya dan kinerja aktual yang dirasakannya setelah pemakaian. Kepuasan pasien/pelanggan adalah inti dari pemasaran yang berorientasi kepada pasien/pelanggan. Pelayanan yang memuaskan dan berkualitas akan membentuk loyalitas pasien/pelanggan, dan kepuasan sangat erat hubungannya dengan "word of mouth", maka pelayanan yang memuaskan tersebut juga akan mendatangkan pelanggan baru. Efek selanjutnya akan berlanjut pada proses terbentuknya citra puskesmas yang meningkat. Hal ini dikarenakan kondisi persaingan yang sangat ketat. Maka setiap puskesmas akan berusaha untuk menempatkan dirinya sebaik mungkin dimata pasien/pelanggannya agar dapat dipercaya untuk memenuhi kebutuhannya dalam bidang kesehatan (Rangkuti, 2006).

Tempat penerimaan pasien rawat jalan merupakan unit pelayanan terdepan bagi setiap puskesmas. Pelayanan pendaftaran pasien harus mampu mencakup informasi penting mengenai data sosial pasien. Selain itu pemberi pelayanan sebaiknya berpenampilan rapi dan berkomunikasi aktif untuk mendukung pelayanan di puskesmas. Tata cara melayani pasien dapat dinilai baik bilamana dilaksanakan oleh petugas dengan cepat, sikap yang ramah, sopan, tertip dan penuh tanggung jawab. Untuk menciptakan dan menjaga mutu pelayanan medis yang disesuaikan dengan keinginan masyarakat, maka pihak puskesmas perlu suatu umpan baik dari masyarakat yaitu tanggapan dan penilaian dari para pasien sehingga dijadikan sebagai suatu bahan evaluasi dan gambaran apakah pelayanan yang diberikan telah memenuhi harapan pasien atau belum. Oleh karena itu puskesmas berusaha untuk menghasilkan kinerja sebaik mungkin sehingga dapat memuaskan pasien.

Berdasarkan studi pendahuluan yang dilakukan peneliti pada tanggal 28 Juni 2016 di Puskesmas Kretek Bantul Yogyakarta, peneliti melakukan wawancara kepada salah seorang petugas rekam medis di Puskesmas Kretek Bantul Yogyakarta, menurut petugas rekam medis di bagian Tempat Pendaftaran Pasien (TPP) rawat jalan masih terdapat permasalahan mengenai pelayanan yang diberikan, hal ini dapat dillihat dengan adanya pasien yang komplain terhadap petugas TPP. Komplain pasien yang ditujukan kepada petugas TPP berupa komplain terhadap kecepatan petugas pendaftaran yang dikarenakan kurang efisiennya dalam melakukan pendaftaran pasien hal ini dikarenakan lamanya petugas dalam mengentery data pasien.

Memperhatikan masalah diatas peneliti tertarik untuk melakukan penelitian tentang kepuasan pasien terhadap kualitas pelayanan di tempat pendaftaran pasien rawat jalan di Puskesmas Kretek Bantul Yogyakarta. Mengetahui kepuasn pasien diharapkan pelayanan di pendaftaran pasien rawat jalan dapat dimaksimalkan, sehingga pada akhirnya puskesmas tersebut dapat memberi pelayanan yang berkualitas sekaligus memenuhi harapan dan kepuasan pasien.

\section{METODE PENELITIAN}

Jenis penelitian yang digunakan adalah penelitian deskriptif dengan menggunakan pendekatan kuantitatif serta dengan rancangan Cross sectional. Teknik sampel yang digunakan adalah purposive accidental. Sampel yang diambil sebanyak 100 orang pasien. Teknik pengumpulan data menggunakan angket dan obsevasi. Teknik analisa data menggunakan statistik deskriptif dengan menggunakan uji statistik Kruskal-Wallis dan Mann-Whitney.

\section{HASIL DAN PEMBAHASAN}

\section{A. Hasil Penelitian}

1. Karakteristik responden

Berdasarkan pengambilan data yang telah dilakukan menggunakan kuesioner kepada 100 responden di Puskesmas Kretek bantul karakteristik responden pada jenis kelamin laki-laki dan 
perempuan berimbang. Adapun untuk kelompok usia 35-39 dan 45-49 tahun, pendidikan SMA, dan pekerjaan Buruh menempati posisi tertinggi.

2. Tingkat kepuasan pasien terhadap pelayanan di tempat pendaftaran rawat jalan secara keseluruhan berdasarkan lima dimensi kualitas jasa

Pengukuran tingkat kepuasan pasien atau keluarga pasien di TPP rawat jalan dilakukan terhadap 100 orang responden berdasarkan kuesioner yang berisi 20 butir item pernyataan yang telah terkumpul, ditabulasi dan dilakukan analisis statistik. Pada tabel 5. Menunjukan 12 (12\%) responden menyatakan sangat puas, 84 (84\%) responden menyatakan puas dan 4 (4\%) responden menyatakan cukup puas.

\section{a. Tangibles}

Tingkat kepuasan pasien di TPP rawat jalan puskesmas Kretek pada dimensi tangiles sebanyak 39 (39\%) responden menyatakan sangat puas, 59 (59\%) responden menyatakan puas dan $2(2 \%)$ responden menyatakan cukup puas.

\section{b. Reliability}

Tingkat kepuasan pasien di TPP rawat jalan puskesmas Kretek pada dimensi reliability sebanyak 29 (29\%) responden menyatakan sangat puas, 62 (62\%) responden menyatakan puas dan $9(9 \%)$ responden menyatakan cukup puas.

\section{c. Responsiveness}

Tingkat kepuasan pasien di TPP rawat jalan puskesmas Kretek pada dimensi responsiveness sebanyak 25 (25\%) responden menyatakan sangat puas, 63 (63\%) responden menyatakan puas dan 12 (12\%) responden menyatakan cukup puas.

\section{d. Assurance}

Tingkat kepuasan pasien di TPP rawat jalan puskesmas Kretek pada dimensi assurance sebanyak 26 (26\%) responden menyatakan sangat puas, 54 (54\%) responden menyatakan puas, 18 $(18 \%)$ responden menyatakan cukup puas dan $2(2 \%)$ responden menyatakan tidak puas.

e. Emphaty

Tingkat kepuasan pasien di TPP rawat jalan puskesmas Kretek pada dimensi emphaty sebanyak 29 (29\%) responden menyatakan sangat puas, 62 (62\%) responden menyatakan puas dan 9 (9\%) responden menyatakan cukup puas.

3. Perbedaan Tingkat kepuasan pasien terhadap lima dimensi kualitas jasa di tempat pendaftaran pasien rawat jalan Puskesmas Kretek ditinjau dari karakteristik pasien.

a. Jenis kelamin

Berdasarkan uji mann-whitney menunjukan asymp.sig sebesar 0,152. Sehingga diketahui bahwa P (sig.) > 0,05 maka Ho diterima dan $\mathrm{H} 1$ ditolak. Maka dapat disimpulkan bahwa tidak ada perbedaan tingkat kepuasan pasien terhadap pelayanan di tempat pendaftaran pasien rawat jalan ditinjau dari karakteristik jenis kelamin pasien.

b. Usia

Berdasarkan hasil uji statistik menggunakan uji kruskal-wallis bahwa $\mathrm{P}$ (sig.) sebesar $=0,088$. Sehingga diketahui bahwa $\mathrm{P}$ (sig.) $>0,05$ maka Ho diterima dan $\mathrm{H} 1$ ditolak. Maka dapat disimpulkan bahwa tidak ada perbedaan tingkat kepuasan pasien terhadap pelayanan di tempat pendaftaran pasien rawat jalan ditinjau dari karakteristik usia pasien.

c. Pekerjaan

Berdasarkan hasil uji statistik menggunakan uji kruskal-wallis bahwa $\mathrm{P}$ (sig.) sebesar $=0,148$. Sehingga diketahui bahwa $\mathrm{P}$ (sig.) > 0,05 maka Ho diterima dan $\mathrm{H} 1$ ditolak. Maka dapat disimpulkan bahwa tidak ada perbedaan tingkat kepuasan pasien terhadap pelayanan di tempat pendaftaran pasien rawat jalan ditinjau dari karakteristik pekerjaan.

d. Pendidikan Pasien

Berdasarkan hasil uji statistik menggunakan uji kruskal-wallis bahwa $\mathrm{P}$ (sig.) sebesar $=0,003$. Sehingga diketahui bahwa $\mathrm{P}$ (sig.) $<0,05$ maka H1 
diterima dan Ho ditolak. Maka dapat disimpulkan bahwa ada perbedaan tingkat kepuasan pasien terhadap pelayanan di tempat pendaftaran pasien rawat jalan ditinjau dari karakteristik pendidikan pasien. Analisis selanjutnya adalah dengan metode mann-whitney (post hoc test) untuk melihat perbedan dari masing-masing pendidikan. Tabel 12 menunjukan bahwa $\mathrm{P}$ (sig.) $<0,05$ pada karakter pendidikan tidak sekolah dengan SD, tidak sekolah dengan SMP, tidak sekolah dengan SMA dan tidak sekolah dengan Perguruan Tinggi sehingga ada perbedaan kepuasan yang bermakna pada karakteristik tersebut.

\section{B. Pembahasan}

1. Tingkat kepuasan pasien terhadap pelayanan di tempat pendaftaran pasien rawat jalan berdasarkan lima dimensi kualitas jasa.

Menurut Kotler (2005), kualitas pelayanan adalah keseluruhan ciri serta sifat dari suatu produk atau pelayanan yang berpengaruh pada kemampuannya untuk memuaskan kebutuhan yang dinyatakan atau tersirat. Dengan demikian, yang dimaksud dengan mutu pelayanan kesehatan adalah yang menunjukkan pada tingkat kesempurnaan pelayanan kesehatan dalam menimbulkan rasa puas pada diri setiap pasien.

Berdasarkan distribusi frekuensi seperti yang terangkum dalam tabel 5, dapat diketahui bahwa kepuasan pasien secara keseluruhan di Tempat Pendaftaran Pasien Rawat Jalan Puskesmas Kretek Bantul Yogyakarta, dari 100 responden, sebagian besar menyatakan puas (84\%). Sebanyak $12 \%$ responden menyatakan sangat puas dan $4 \%$ responden menyatakan cukup puas. Tidak ada responden yang menyatakan kurang puas maupun tidak puas terhadap pelayanan di tempat pendaftaran pasien rawat jalan Puskesmas Kretek Bantul Yogyakarta.
Dilihat dari statistik deskriptif, diperoleh rerata (mean) sebesar 3,91 yang berada pada interval antara 3,401 s.d 4,201 termasuk dalam kategori puas. Dengan demikian dapat dikatakan bahwa tingkat kepuasan pasien rawat jalan di tempat pendaftaran pasien rawat jalan Puskesmas Kretek Bantul Yogyakarta berada pada kategori puas.

\section{a. Tangibles}

Menurut Arikunto (2006) karena jasa tidak dapat diamati secara langsung maka pelanggan sering kali berpedoman pada kondisi yang terlihat mengenai jasa dalam melakukan evaluasi. Berdasarkan hasil analisis data, dapat diketahui bahwa kepuasan pasien di Tempat Pendaftaran Pasien Rawat Jalan Puskesmas Kretek Bantul Yogyakarta, pada dimensi tangibles, sebagian besar responden menyatakan puas (59\%). Sebanyak 39\% responden menyatakan sangat puas dan $2 \%$ responden menyatakan cukup puas. Tidak ada responden yang menyatakan tidak puas maupun sangat tidak puas terhadap pelayanan di tempat pendaftaran pasien rawat jalan Puskesmas Kretek Bantul Yogyakarta. Dengan demikian, dapat disimpulkan bahwa mayoritas pasien puas terhadap dimensi tangibles di Puskesmas Kretek Bantul Yogyakarta.

b. Reliability

Menurut Tjitono (2007), dimensi reliability menunjukkan kemampuan perusahaan dalam memberikan pelayanan atau jasa yang diharapkan secara meyakinkan, cepat, akurat, andal, dan konsisten. Berdasarkan hasil analisa data pada dimensi reliability, dapat diketahui bahwa kepuasan pasien di tempat pendaftaran pasien rawat jalan Puskesmas Kretek Bantul Yogyakarta, sebagian besar respon menyatakan puas $(62 \%)$, sebanyak $29 \%$ responden menyatakan sangat puas dan 9\% responden menyatakan cukup puas. Tidak ada responden yang menyatakan tidak puas maupun sangat tidak puas terhadap pelayanan di tempat 
pendaftaran pasien rawat jalan. Sehingga dapat disimpulkan bahwa secara umum mayoritas pasien percaya akan keandalan dan keakuratan pelayanan yang diberikan petugas dengan cepat. Serta dengan keandalan yang dimiliki petugas, petugas mampu bersikap adil dalam memberikan pelayanan kepada pasien tanpa membedakan status sosial atau faktor lainnya (tidak bersikap diskriminasi).

\section{c. Responsiveness}

Dimensi responsiveness menunjukkan kesediaan penyedia jasa terutama staffnya untuk membantu serta memberikan pelayanan yang tepat sesuai kebutuhan konsumen. Dimensi ini menekankan pada sikap dari penyedia jasa yang penuh perhatian dan tanggap dalam memberikan pelayanan. Yakni menghadapi permintaan, pertanyaan, keluhan dan masalah konsumen dengan penyampaian informasi yang jelas. Berdasarkan hasil analisis data pada dimensi responsivenes, dapat diketahui bahwa kepuasan pasien di tempat pendaftaran pasien rawat jalan Puskesmas Kretek Bantul Yogyakarta, sebagian besar responden menyatakan puas (63\%). Sebanyak 25\% responden menyatakan sangat puas, dan $12 \%$ responden menyatakan cukup puas. Tidak ada responden yang menyatakan tidak puas dan sangat tidak puas terhadap pelayanan di tempat pendaftaran pasien rawat jalan.

Dengan demikian, dapat disimpulkan bahwa sebagian besar pasien percaya akan kesiapan petugas dalam membantu pasien apabila ada kesulitan, ketanggapan dan kemampuan petugas membantu pasien menyelesaikan masalah yang dihadapi serta ketanggapan petugas dalam memberikan informasi pelayanan yang akan diberikan secara jelas ketika di tempat pendaftaran pasien rawat jalan Puskesmas Kretek Bantul Yogyakarta/

d. Assurance

Dimensi assurance ini menekankan pada kemampuan penyedia jasa untuk membangkitkan rasa percaya dan keyakinan diri konsumen bahwa pihak penyedia jasa terutama pegawainya mampu memenuhi kebutuhan konsumennya, serta memberikan pelayanan dengan kepastian dan bebas dari keragu-raguan. Membiarkan konsumen menunggu tanpa adanya suatu alasan yang jelas menyebabkan persepsi yang negative dalam kualitas pelayanan. Berdasarkan hasil analisis data pada dimensi assurance, dapat diketahui bahwa kepuasan pasien di tempat pendaftaran pasien rawat jalan Puskesmas Kretek Bantul Yogyakarta, sebagian besar responden menyatakan puas (54\%). Sebanyak 26\% responden menyatakan sangat puas, $18 \%$ responden menyatakan cukup puas dan $2 \%$ responden menyatakan tidak puas.

Tidak ada responden yang menyatakan sangat tidak puas dan mayoritas reponden menyatakan puas terhadap pelayanan di tempat pendaftaran pasien rawat jalan. Maka dapat diartikan bahwa sebagian besar pasien merasa yakin dan percaya kepada kemampuan petugas dalam melayani pasien dengan baik. Selain itu, pasien juga tidak dibiarkan menunggu tanpa adanya kepastian ketika mendapatkan pelayanan di tempat pendaftaran pasien rawat jalan Puskesmas Kretek Bantul Yogyakarta.

e. Emphaty

Dimensi emphaty menunjukkan kemampuan penyedia jasa dalam memberikan perhatian yang tulus dan bersifat individual yang diberikan kepada konsumen dengan berupaya memahami keinginannya. Dimensi ini merupakan kemampuan penyedia jasa dalam memperlakukan konsumen sebagai individu-individu yang spesial. Berdasarkan hasil analisis data pada dimensi emphaty, dapat diketahui bahwa kepuasan pasien di Tempat Pendaftaran Pasien Rawat Jalan Puskesmas Kretek Bantul Yogyakarta, sebagian besar responden menyatakan puas (67\%). Sebanyak $17 \%$ responden menyatakan sangat puas dan $17 \%$ responden menyatakan cukup puas. 
Dengan demikian, dapat disimpulkan bahwa sebagian besar pasien menilai petugas telah bersikap ramah dan sopan santun, serta selalu memberikan salam dan bertanya keperluan pasien ketika memberikan pelayanan di Tempat Pendaftaran Pasien Rawat Jalan Puskesmas Kretek Bantul Yogyakarta.

2. Analisis tingkat kepuasan berdasarkan lima dimensi kualitas jasa ditinjau dari karakteristik pasien.

a. Jenis kelamin

Berdasarkan hasil analisis data dengan menggunakan teknik mann-whitney diperoleh hasil bahwa tidak ada perbedaan yang signifikan pada tinggkat kepuasan pasien ditinjau dari karakteristik jenis kelamin. Hal ini ditunjukkan dengan hasil $\mathrm{P}$ (sig). >0,05 yang berarti tidak ada perbedaan yang bermakna pada tingkat kepuasan pasien maka Ho diterima dan H1 ditolak. Pada penelitian anekelita (2013) dari hasil uji $\mathrm{T}$ diperoleh selisih rerata (mean) tingkat kepuasan pasien antara kelompok pasien laki-laki dan pasien perempuan diperoleh hasil bahwa tidak ada perbedaan yang signifikan antara kelompok jenis kelamin, hal ini ditunjukkan dengan hasil $\mathrm{P}$ (sig.) $>0,05$ yang berarti tidak ada perbedaan yang signifikan pada tingkat kepusan pasien

b. Usia

Berdasarkan hasil analisis data dengan menggunakan teknik KruskalWallis diperoleh hasil bahwa tidak ada perbedaan yang signifikan pada tinggkat kepuasan pasien ditinjau dari karakteristik usia. Hal ini ditunjukkan dengan hasil $\mathrm{P}(\mathrm{sig})$. >0,05 yang berarti bahwa tidak ada perbedaan yang signifikan pada tingkat kepuasan pasien. Pada penelitian Anekelita (2013), dari hasil uji Anova pada tingkat kepuasan ditinjau dari karakteristik pasien, didapat hasil bahwa tidak ada perbedaan yang signifikan pada tingkat kepuasan pasien ditinjau dari kelompok usia pasien. Hal ini ditunjukkan dengan
$P($ sig). $>0,05$, yang berarti bahwa tidak ada perbedaan yang bermakna antara kelompok usia.

c. Pekerjaan

Tingkat kepuasan pasien ditinjau dari karakteristik jenis pekerjaan, diperoleh hasil bahwa tidak ada perbedaan yang signifikan. Hal ini ditunjukkan dengan hasil P (sig). > 0,05 yang berarti tidak ada perbedaan yang bermakna pada tingkat kepuasan pasien. d. Pendidikan

Dari hasil analisis data, tingkat kepuasan pasien ditinjau dari karakteristik tingkat pendidikan, diperoleh hasil bahwa ada perbedaan yang bermakna pada tingkat kepuasan pasien. Hal ini ditunjukkan dengan hasil P (sig). <0,05 yang berarti bahwa ada perbedaan yang signifikan pada tingkat kepuasan pasien berdasarkan karakter pendidikan.

Hal ini dibuktikan dengan hasil analisis dengan metode Mann-Whitney (post hoc test) untuk tabel 12, dapat diketahui bahwa ada perbedaan yang bermakna kepuasan pasien antara kelompok pasien yang tidak sekolah dengan kelompok pasien yang berpendidikan SD, kelompok pasien yang tidak sekolah dengan kelompok pasien yang berpendidikan SMA dan kelompok pasien yang tidak sekolah dengan kelompok pasien yang berpendidikan Perguruan Tinggi.

\section{PENUTUP}

A. Kesimpulan

1. Karakteristik responden pada jenis kelamin laki-laki dan perempuan berimbang. Adapun untuk kelompok usia 35-39 dan 45-49 tahun, pendidikan SMA, dan pekerjaan Buruh menempati posisi tertinggi.

2. Distribusi kepuasan secara menyeluruh mayoritas pada kategori puas. Dilihat dari setiap dimensi masih ada kategori tidak puas pada dimensi assurance khususnya item 
B. Saran

pasien yakin akan kemampuan petugas.

3. Tidak ada perbedaan kepuasan berdasarkan karakteristik Jenis kelamin, Usia, dan Pekerjaan. Namun ada perbedaan kepuasan yang bermakna pada karakteristik pendidikan.

Kepala puskesmas sebaiknya menyelenggarakan pelatihan kepada petugas TPP untuk meningkatkan kompetensi/ kemampuan sehingga dapat lebih memberikan pelayanan dengan kepastian yang baik, dapat memberikan rasa percaya dan keyakinan diri pasien terhadap kemampuan petugas dalam memberikan pelayanan, serta tidak membiarkan pasien menunggu tanpa adanya kejelasan petugas.

\section{DAFTAR PUSTAKA}

Arikunto, S. (2006). Prosedur Penelitian Suatu Pendekatan Praktek Revisi V. Jakarta: Rineka Cipta.

Aritonang, L. R. (2005). Kepuasan Pelanggan. Jakarta: Gramedia Pustaka Utama.

Azwar,A. (1996). Pengantar Administrasi Kesehatan. Jakarta: Bina Rupa Aksara.

Azwar,S. (2009). Metode Penelitian. Yogyakarta: Pustaka Pelajar.

Benyamin. (1990). Pelayanan Media Citra Konflik dan Harapan. Yogyakarta: Kanisius.

Budi,S.C. (2011). Manajemen Unit Kerja Rekam Medis. Yogyakarta: Quantum Sinergis Media.

Depkes RI. (1997). Pedoman Pengelolaan Rekam Medis Rumah Sakit Di Indonesia Revisis I. Jakaarta: Direktorat Jenderal Pelayanan Medik Departemen Kesehatan Republik Indonesia.

Dessler, G. (2009). pengertian Pelatihan. http://teorionline.wordpress.com/201 0/0 6/27/pelatihan-sdm. Diakses Tanggal 8 November 2016.
Huffman, E, K. (1994). Health Information Management. Berwyn: Illionis Physician's Record Company.

Kotler, P. (2005). Manajemen Pemasaran Edisi II. Jakarta: Indeks.

Notoatmodjo, S. (2005). Metodologi Penelitian Kesehatan. Jakarta: Rineka Cipta

Noviandine, A. (2013). Kepuasan Pasien Jamkesmas Terhadap Pelayanan Petugas Di TPP Rawat jalan RSUD DR. Soeradji Tirtonegoro Klaten. Karya Tulis Ilmiah. Yogyakarta: DIII Rekam Medis Dan Informasi Kesehatan FMIPA UGM (tidak dipublikasikan)

Noviyani, R. (2009). Kepuasan Pasien Askes Terhadap Pelayanan Petugas Tempat Penerimaan Pasien (TPP) Rawat Jalan RSUP Dr. Sardjito Yogyakarta. Karya Tulis Ilmiah. Yogyakarta: DIII Rekam Medis dan Informasi Kesehatan FMIPA UGM (tidak dipublikasikan).

Peraturan Menteri Kesehatan Republik Indonesia Nomor 269 / Menkes / Per / III / 2008 tentang Rekam Medis. http://dinkes.surabaya.go.id/portal/f iles/ permenkes/dok_dinkes_87.pdf Diakses Tanggal 8 November 2016.

Rangkuti, F. (2006). Measuring Customer Satisfaction. Jakarta: Gramedia Pustaka Utama.

Sugiyono. (2012). Metode Penelitian Kuantitatif Kualitatif dan R\&D. Bandung: Alfabeta.

Sugiyono. (2012). Reliabilitas dan Validitas Edisi 4. Bandung: Alfabeta.

Supranto, J. (2002). Metode Riset Aplikasi dalam Pemasaran. Jakarta: Rineka Cipta.

Supranto, J. (2006). Pengukuran Tingkat Kepuasan Pelanggan Untuk Menaikkan Pangsa Pasar. Jakarta: Rineka Cipta.

Suprapto, K. M. (2008). Kepuasan Pasien Terhadap Pelayanan Di Tempat Pendaftaran Pasien Rawat Jalan Rumah Sakit Mata Dr. "YAP" Yogyakarta. Karya Tulis Ilmiah. Yogyakarta: DIII Rekam Medis dan 
Informasi Kesehatan FMIPA Universitas Gadjah Mada.

Tjiptono, F. (2007) Pemasaran Jasa (Services Marketing). Yogyakarta: Andi. 